\title{
Recycling of Kotah Stone Quarry Waste and Manufacturing Normal Portland Cement: A Conceptual Technology of Future
}

\author{
Satish Chand Agarwal \\ Associated Stone Industries (Kotah) Ltd., Kota, India \\ Email address: \\ scagarwal42@yahoo.com
}

\section{To cite this article:}

Satish Chand Agarwal. Recycling of Kotah Stone Quarry Waste and Manufacturing Normal Portland Cement: A Conceptual Technology of Future. Journal of Chemical, Environmental and Biological Engineering. Vol. 3, No. 2, 2019, pp. 19-24.

doi: $10.11648 /$ j.jcebe.20190302.12

Received: June 16, 2019; Accepted: September 26, 2019; Published: October 31, 2019

\begin{abstract}
The State of Rajasthan in India, has abundant reserves of Flaggy Limestone which yields Kotah Stone. It is very popular and widely known as best and most economical flaggy stone within country and abroad. The deposit of Kotah Stone is generally confined to $15 \mathrm{mtr}$. in thickness. It is overlaid by a zone of non splittable limestone waste layers. This waste zone has increased from ' 0 ' in 1945 to present 40 - 45mtr, oue to dipping rocks @ $7-15 \%$. To a general estimate, over the years of mining some 550Mill. Ton of such waste has piled up in entire belt in form of man-made mountains. This has caused serious environmental problem beside economic hazard arising from its disposal and management. Beside reduction, recycling and utilization of quarry waste is perhaps the only solution for industrial survival. A serious effort has been made to utilize by recycling this waste for manufacturing normal Portland Cement. This waste having low in $\mathrm{CaO} 38 \%$ and high in Silica 23\% needed beneficiation. Exhaustive test and studies on wet beneficiation have established that it is technically feasible to enrich the $\mathrm{CaO}$ to $44 \%$ and reduce Silica to $12-33 \%$, a feed product most suitable for manufacture of Ordinary Portland Cement of 53\% grade. ACC Madukkarai cement plant had conducted beneficiation studies in 2004-17 on its low grade limestone containing $43 \% \mathrm{CaO}$ and $18 \%$ Silica to use the concentrate as additive to normal raw material to cement plant. Present paper highlights the various activities of the project in manufacturing cement using concentrate after beneficiation of much low grade limestone. The technique suggested and cost of beneficiation vis-vis environmental merits of the project have been discussed.
\end{abstract}

Keywords: Kotah Stone, Quarry Waste, Recycling, Grinding, Beneficiation, Clinker, Portland Cement

\section{Introduction}

The State of Rajasthan has been gifted by nature with abundan deposit of flaggy limestone which yields Kotah stone. It is very popular and widely known as best and most economical flooring stone within country and abroad.

The deposit belongs to Semri series of lower Vindhyas. Mining of Kotah stone has been going on since 1945 and production has substantially increased from a few lac sq.ft. to $45 \mathrm{Cr}$. sft., annually as on today. The deposit of Kotah stone is generally confined to $15 \mathrm{mtr}$. In thickness. It is natural splitable in some 240-260 splits, compact in nature and goods for commercial use [1].

\section{Generation \& Disposal of Waste}

The deposit is over laid by a zone of overburden which is non splitable lime stone layers. The thickness of O. B. has been increasing year after year as per the grade of deposit, ranging from $7 \%$ - $25 \%$. It has increased from zero in thickness in 1945 to as much as 45mtr in 2010-11.

For exposing the layers of Kotah stone this over lying burden has to be excavated, transported and dumped at the distance. Besides this some quantity of waste is generated at production floor during sizing and cutting of slabs and tiles.

Thus Waste in Kotah Stone mining generates at 2 points: 
1. During excavation of overburden and this constitutes $90 \%$ of the total waste generated.

2. During sizing and cutting of Kotah stone slab and tiles at quarry level which amounts to remaining $10 \%$ of total waste.

Over the years of mining waste have generated at an exponential rate as evident from the following statistics collected from a largest leaseholder.

$\begin{array}{ll}\text { Years } & \text { Quantity } \\ 1959-1980 & 2.0 \text { Mill. Ton } \\ 1981-1990 & 8.5 \text { Mill. Ton } \\ 1991-2000 & 38.0 \text { Mill. Ton } \\ 2001-2010 & 95.0 \text { Mill. Ton }\end{array}$

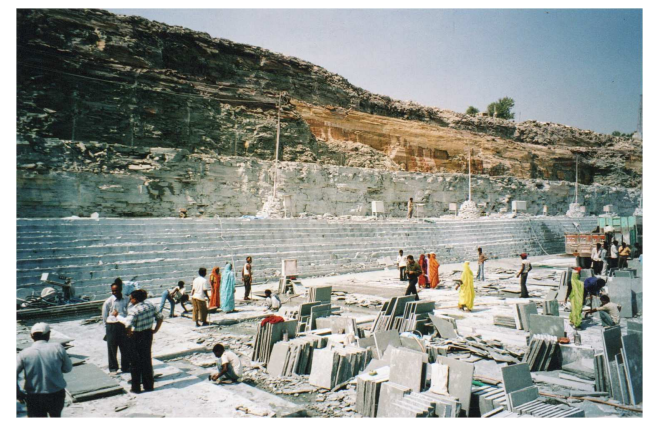

Figure 1. Typical working mines of kotah stone quarry.

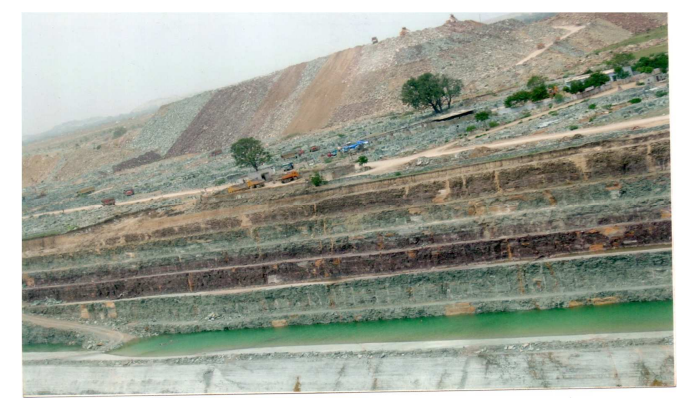

Figure 2. Dump material of kotah stone quarry.

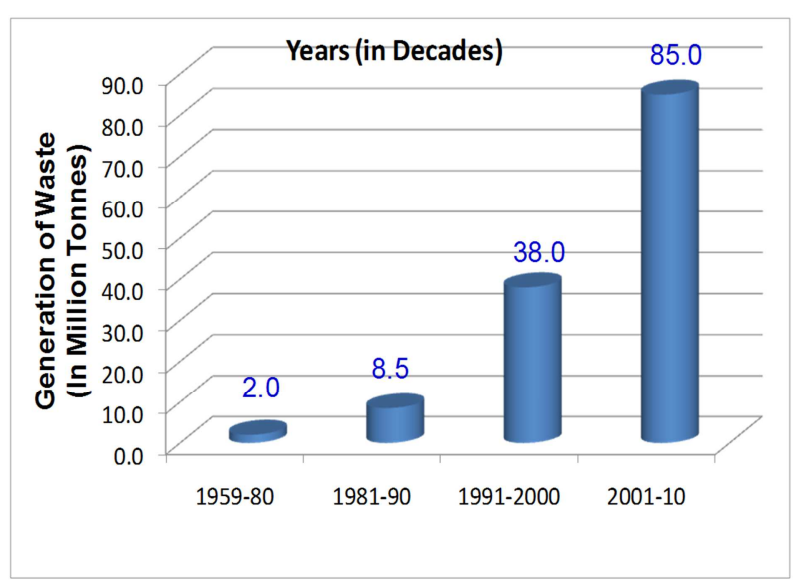

Figure 3. Generation of waste OB material.

To a general estimate some 500Mill. MT of waste has piled in the entire belt of Kotah stone mining. A further annual generation of 25-27Mill. MT is continuing.

Disposal of such huge waste has posed serious problem.
Inspite of back filling the waste in the exhausted area, the dumps of waste have raised to a height of 30Mtr. above from ground level. Man made mountains of waste could be seen around the mining area of Kotah stone. The waste has caused serious economic as well as environmental problems in its management and disposal. Some of them are as below.

1. It has added to the cost of mining of Kotah stone from 0.50sq.ft. in 1990 to Rs 2/- Sq.ft. in 2010.

2. A large fleet of HEMM has been deployed for excavation, transportation and dumping. During the entire process a huge quantity of dust has generated from excavation to dumping, polluting the environment.

3. All equipments deployed for waste handling are diesel operated. To an estimate $\mathrm{CO}_{2}$ emission from these equipments, at this particular location alone, has substantially increased to 7300 Ton per annum. This emission is increasing year after year proportionate to quantity of waste.

4. All around the area man made mountains has changed the aesthetic look of the surrounding area [1].

5. After extraction of Kotah stone land could not be reclaimed back to the ground level for original land use.

6. Regional pollution has increased due to increase in Carbon dioxide emission, dust pollutant generated during vehicle operation, drilling and blasting.

\section{Utilization of Waste}

Waste has always been big news to business watching what you throw away at the end of production. It is almost as important as the finished products. Company is now involved in waste minimizing technology and waste utilization project.

Minerlogically the O. B. waste from Kotah stone mining is Low grade Limestone, a typical analysis is as given in Table $1[2]$.

Table 1. Typical Analysis of Kotah Stone Waste.

\begin{tabular}{ll}
\hline Constituents & Results \% \\
\hline Loss on Ignition $(\mathrm{LOI})$ & 31.20 \\
Silica $\left(\mathrm{SiO}_{2}\right)$ & 23.50 \\
Iron Oxide $\left(\mathrm{Fe}_{2} \mathrm{O}_{3}\right)$ & 1.94 \\
Aluminum Oxide $\left(\mathrm{Al}_{2} \mathrm{O}_{3}\right)$ & 3.10 \\
Calcium Oxide $(\mathrm{CaO})$ & 37.85 \\
Magnesium Oxide $(\mathrm{MgO})$ & 1.20 \\
\hline
\end{tabular}

The waste thus has high Silica content and low calcium. Commercial utilization of this waste has always been a great concern. Using in small quantity for one or the other purpose is of no value, when compared to quantity generated in combating the environmental impact.

\subsection{Cement Making}

Perhaps using this waste in manufacturing cement is the only way where a large quantity can be used. The limestone mines are widely scattered in many parts of India fulfilling the demand of steel, cement and chemicals industries. Traditionally, the growth of Indian cement industry is directly related to the growth of the country's economy. It is expected 
that both cement consumption and production will grow substantially during the coming years.

Cement is a fine powdery substance which is made from a mixture of natural materials such as limestone and clay. Four elements such as calcium, silicon, aluminum and iron obtained from the raw materials are essential for cement making [14]. When cement is mixed with water, it can bind sand into a hard, solid mass called concrete. The demand of quality limestone has increased due to the rapid expansion of the existing cement plants and commissioning of more and more new cement plants. The most desirable property of limestone for cement making is that it should contain atleast $45 \% \mathrm{CaO}$ for the manufacture of varieties of cement. It is often seen that the availability of cement grade limestone is scanty in our country and the future cement industry will mostly depend on low grade ore containing higher impurities.

\subsubsection{By Blending}

But for high silica and low calcium it cannot be used directly for cement manufacturing unless it is mixed with high grade limestone having silica less than $1.5 \%$ and $\mathrm{CaO}$ more than $52 \%$. The feasibility of mixing quarry waste with high grade limestone has been examined. It has been worked out that atleast $50 \%$ of high grade limestone would be required for getting the raw mix suitable for cement [15]. Out sourcing of such large quantity from distantly located mines is neither economical nor feasible.

\section{OFFERED PROCESS FLOW SCHEME}

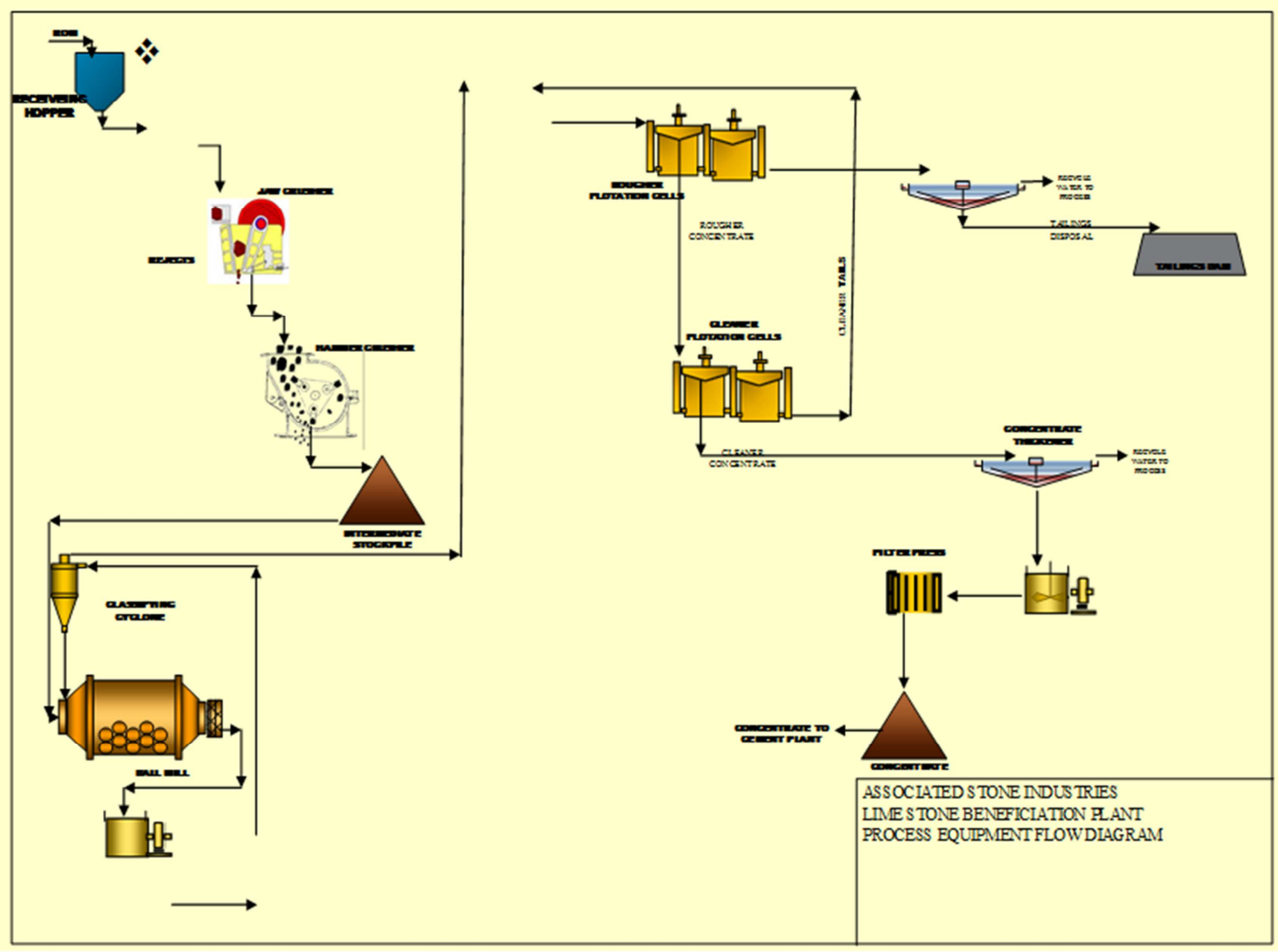

Figure 4. Offered Process Flow Scheme.

\subsubsection{By Beneficiation}

If the quality limestone as specified for cement making is not available, it is generally beneficiated to increase the $\mathrm{CaO}$ content. It is therefore essential to exploit the low grade deposit or from the secondary sources to meet the requirement of the industry. The beneficiation of limestone will therefore play an important role in future days to come to meet the demand of cement raw material [9].

In general, low grade limestone is beneficiated by size reduction followed by froth floatation using a suitable reagent [11]. In India beneficiation of low grade limestone is practiced only in limited cement plants. Fatty acids and their derivatives are generally used as the collectors for the effective flotation of calcite values. In reverse flotation of limestone, quartz is floated directly with powerfully cationic reagents $[10,12]$. The calcite depressants in such cases are tannin and quebracho. Inspite of successful beneficiation of carbonate minerals, the details characterization studies of the limestone deposit are very much essential as the deposits varies from place to place and admixed with varieties of impurities such as S, P, C, alpha quartz etc [4-8].

Limestone containing about $45 \% \mathrm{CaO}$ and above is usually preferred for the manufacture of cement. The other elemental composition such as $\mathrm{MgO}$ content in the stone should be $<$ 
$3 \%, \mathrm{~S}$ and $\mathrm{P}$ should be low as possible since they are regarded as the most undesirable impurities and reduce the setting time of cement. The cement industry in India in general is prescribed with the following specification of limestone.

$\begin{array}{lll}\text { I } & \mathrm{CaO} & 42 \% \text { (min.) } \\ \text { II } & \mathrm{Al}_{2} \mathrm{O}_{3} & 2 \text { to } 2 \% \text { (min.) } \\ \text { III } & \mathrm{Fe}_{2} \mathrm{O}_{3} & 1-2 \% \\ \text { IV } & \mathrm{SiO}_{2} & 12 \text { to } 16 \% \\ \text { V } & \mathrm{MgO} & 4 \% \text { (max.) }\end{array}$

\subsubsection{Beneficiation Studies}

Intensive test studies were carried out at one of the leading mineral processing research laboratory, Govt. of India [3], and also at one of the leading test center in USA. The results of the investigation revealed that the Kotah stone quarry waste is amenable to beneficiation by flotation technique with different re-agents.

Table 2. The details of laboratory trial test conducted on quarry waste for beneficiation are given below.

\begin{tabular}{llll}
\hline \multirow{2}{*}{ Oxides } & LG Limestone & \multicolumn{2}{c}{ Assay \% Concentrate } \\
\cline { 3 - 4 } & (ROM) & (Indian Lab.) & (USA Lab.) \\
\hline $\mathrm{CaO}$ & 37.85 & 44.50 & 43.20 \\
$\mathrm{MgO}$ & 1.25 & 1.60 & 0.619 \\
$\mathrm{SiO}_{2}$ & 23.50 & 13.10 & 11.60 \\
$\mathrm{Fe}_{2} \mathrm{O}_{3}$ & 1.94 & 2.00 & 0.901 \\
$\mathrm{Al}_{2} \mathrm{O}_{3}$ & 3.10 & 1.70 & 2.04 \\
$\mathrm{LOI}$ & 31.20 & 35.84 & 36.20 \\
\hline
\end{tabular}

Taking all experiments into consideration it has been concluded that concentrate with $\mathrm{CaO}$ grade of $44 \%$ with more than $65 \%$ yield can be obtained. This is suitable for cement manufacturing. A suitable flow sheet has been developed.

\section{FLOATATION PROCESS}

* Grinding of mineral ore to slurry

* Chemical conditioning

* Contacting mineral particles with air bubbles

* Recovery of the concentrate as froth

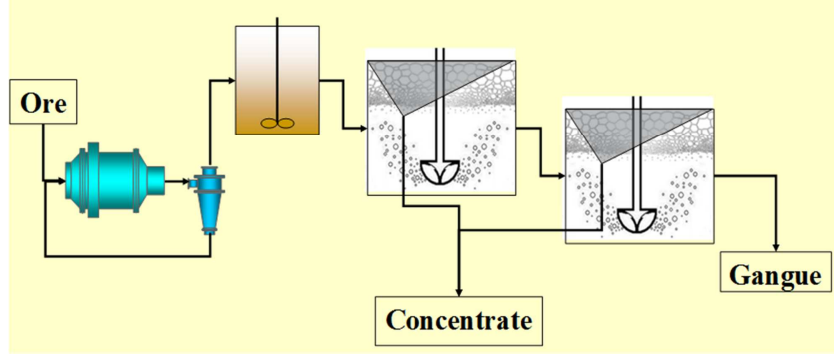

Figure 5. Floatation Process.

Based on these studies a process has been developed wherein the waste overburden material shall be crushed to product size less than $12 \mathrm{~mm}$ and further ground to below 100 micron in a close circuit ball mill with hydro cyclone to produce the product with $80 \%$ passing size of 90 micron.

The ground product will be conditioned in a conditioner with the required dosages of reagents. The conditioned pulp will be treated in rougher flotation cells and further cleaned in cleaner flotation cells. The concentrate froth obtained from cleaner cell will be thickened in product thickener and subsequently filtered to generate concentrate. The tailings will be thickened in a tailing thickener and will be discarded in the tailing dam. The water from both the thickener and filter will be recycled to the process. Finally concentrate carrying $12-14 \%$ moisture of the grade suitable for clinkerisation would be available.

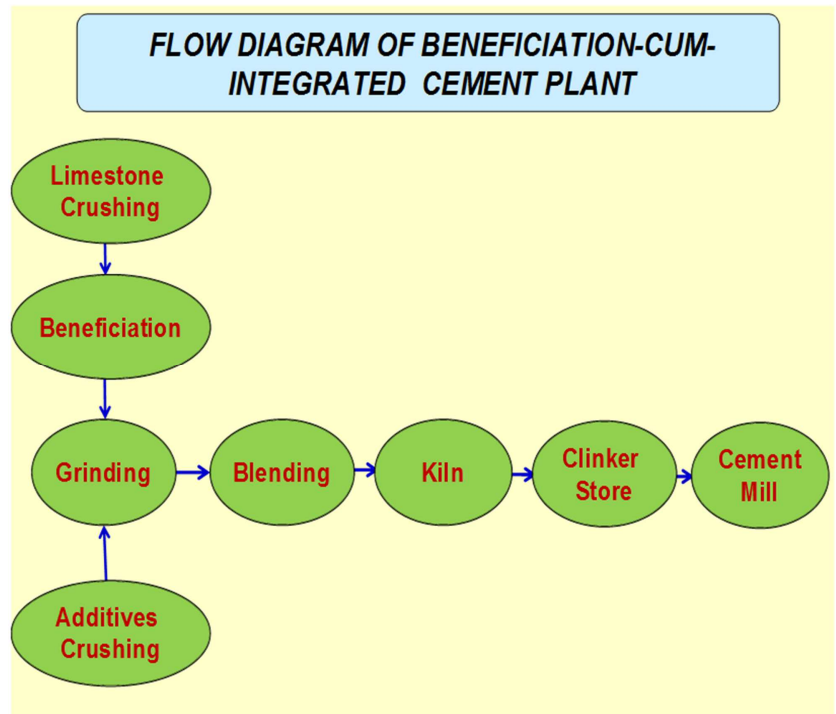

Figure 6. Flow diagram of beneficiation-cum-integrated cement plant.

\section{Cement Manufacturing}

Systematic studies were carried out on utilization of beneficiated limestone as raw material in the manufacture of cement. A number of raw mix were designed using various combinations of beneficiated limestone, high grade limestone, laterite, fly ash and burnability investigations were carried out. A particular raw mix was optimized based on burnability results when beneficiated limestone upto $88 \%$ was used for producing clinker and making OPC [12, 13].

Bulk clinker samples were prepared in the laboratory furnace which indicated the presence of $45 \% \mathrm{C}_{3} \mathrm{~S}$. The optical microscopically analysis indicated that the faces were well developed and homogeneously distributed.

Ordinary Portland cement was prepared from bulk clinker. The results indicated that the cement so produced confirms to all physical and chemical requirement of cement specifications as laid down in BIS [16, 17]. 
Table 3. Properties of OPC produced.

\begin{tabular}{llll}
\hline S. No. & Property & OPC-2B & Requirement of IS-12269-1987 (53 Grade OPC) \\
\hline 1. & Fineness (M2/Kg.) & 281 & Not less than 225 \\
2. & Setting tine in minutes & 110 & Not less than 30 \\
& Initial & 160 & Not more than 600 \\
& Final & & \\
& Compressive strength (MPa) & 33.0 & Not less than 30 \\
3. & 3 days & 46.5 & Not less than 37 \\
& 7 days & 55.0 & Not less than 53 \\
& 28 days & & \\
4. & Soundness & 1.00 & Not more than 10 \\
& Le-chatelier (mm) & 0.04 & Not more than 0.08 \\
\hline
\end{tabular}

The cement manufacturing process will be a dry process which will consists of the following unit operation steps:

1. Drying of concentrate-cum-grinding with corrective raw material.

2. Homogenization of raw meal in a blending Silo.

3. Clinkerisation of raw meal in Rotary Kiln with preheater and pre-calcinator.

4. Cement grinding, storage and package.

The filter cake of beneficiated limestone with $12 \%$ moisture shall be fed to an air swept hammer mill for dis-agglomeration and other additives shall be fed to a closed circuit chamber grinding mill. The drying of material during grinding shall be done by Kiln waste gases.

The rest of the 3 processes in sequence are identical to normal and conventional cement manufacturing process.

\subsection{Suitability of Location}

A project of 1 MTPA clinker capacity has been conceived based on the test studies. The processes of beneficiation which a wet flotation, needs a large quantity of water. To an estimate of beneficiating some 8000 tons of material (equivalent to 1 MTPA clinker) the plant would need 2.4Mill. $\mathrm{M}^{3}$ of water.

Rajasthan being a water scarcity State, such projects would not be entertained if ground water is the source of supply. However, if the plant is located close to the Kotah stone quarry, adequate water would be available from the mines filled up with water during the rainy season. It has been estimated by a Hydrological survey carried out pre-monsoon and post monsoon that even in the situation of scanty rainfall, more than 2.7Mill. $\mathrm{M}^{3}$ water would be available.

Also if the plant is located close to the mines, where a huge quantity of waste has been piled up, it would be economical to transport material to the plant for the entire life. As such the best and the most suitable location of such plant would be close to quarries.

Table 4. Merits/Demarits of Plant: - Capacity 1 MTPA Clinker.

\begin{tabular}{|c|c|c|}
\hline Particular & Conventional Cement Plant & Beneficiation-cum-Cement Integrated Plant \\
\hline 1. Land degradation & 5 Hect./Yr. & NIL \\
\hline 2. Land reclamation & NIL & 5 Hect to G. L/Yr. \\
\hline 3. Use of Ground Water & Major source from Ground water & No use of G. W. To use Rain harvested water only \\
\hline 4. $\mathrm{Co}_{2}$ Emission & $1500 \mathrm{MT} /$ year & 380MT/Yr. \\
\hline 5. Solid Waste Generation & Good quality in form of $\mathrm{OB}$ Waste & 0.87Mill. T/Tailings \\
\hline 6. Waste Recycle & NIL & 2.5Mill. T/yr. \\
\hline 7. Solid Particulate Emission & $\begin{array}{l}\text { Emission of good quantity of dust particulate during grinding of } \\
\text { raw meal }\end{array}$ & No emission due to Wet grinding \\
\hline 8. Power consumption & 76 Units/T of Cement & 132 Units/T Cement \\
\hline 9. Project capital cost & If Rs. X Cr. & Rs. 1.5 X Cr. \\
\hline 10. Cost/T of Clinker & If Rs. Y & Rs. $1.3 \mathrm{Y}$ \\
\hline
\end{tabular}

From the above study it is evident that the cost of product and in case of Integrated Plant is $30 \%$ higher than the production cost from the normal plant. This increase in the cost of production has to be visualized and set off from the benefits and environmental merits that would be emerging from such plant.

\subsection{Environmental Aspects of Project}

The scar marks of abandoned working, the naked dump site of O. B., rocks, dust covered dwelling and total absence of Green patches are the possible scenario of post mining operation of Kotah stone [1].

There will be shifting of employment from Agriculture to mining and subsequently reducing to no employment when Kotah stone deposits get exhausted and Agriculture land gets degraded for mining.

According to Center of Exploitation of Science \& Technology (CEST) the cost of waste is usually about 5 times higher than expected. An environment impact can never be ignored. The proposed project with a conceptual but well established technology will address many environmental and social issues. A few of them are:

1. It would lead to conservation of mineral as it is based on recycling of Kotah stone quarry waste.

2. There will not be any use of ground water. Instead of rain harvested water will only be used. 
3. It will lead to reclamation of high graded land to original land use of agriculture/habitation. It is estimated that some 320 hectare land will be reclaimed in 40 year life span of 1 MTPA plant.

4. There will not be any discharge of hazardous matter.

5. Emission of $\mathrm{CO}_{2}$ will be substantially reduced.

6 . The project will generate employment for atleast 500 people directly employed and many more indirectly employed for a prolonged period.

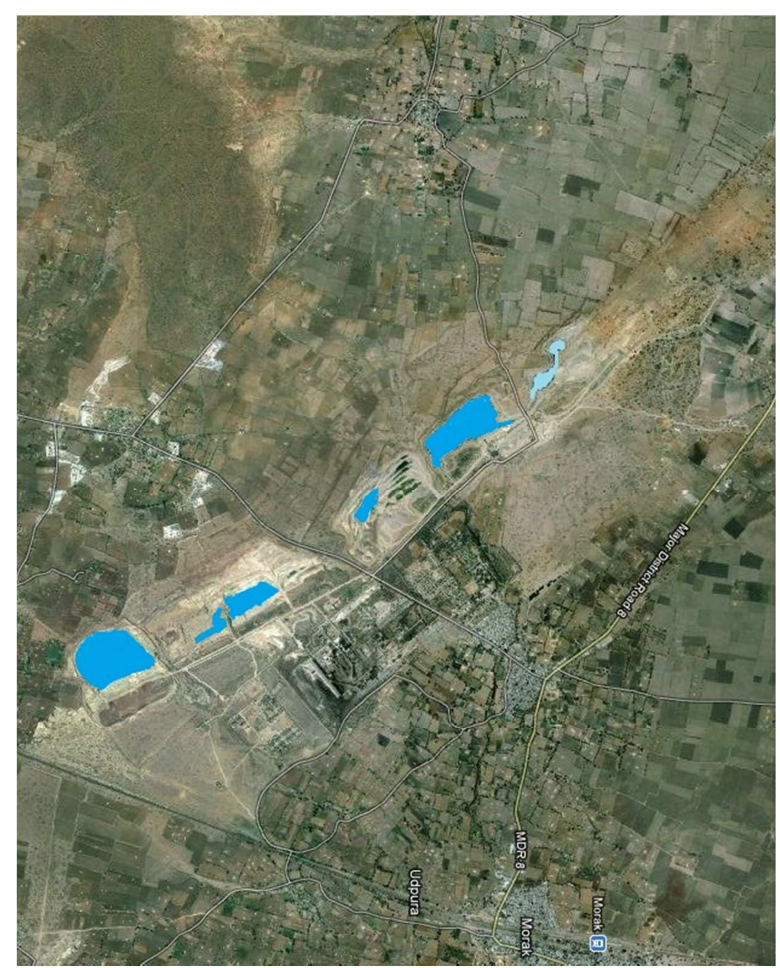

Figure 7. Water storage in mining pits.

\section{Conclusion}

It is rightly said that Green Society will play a key role in the next decade. Recycling, conservation, preservation will be a way of life. All luxuries of wastage and abundance have to go away.

\section{Recommendation}

Conservation of raw material/mineral will be a big factor as material resources are getting scare. We need smart technology to have an ecologically sustainable environment. Here is one such proven technology which needs all out support. Success of one such integrated plant will lead to multiplication of many more such plants.

\section{References}

[1] Agarwal. S. C."Innovating a Clean Technology for Mining Kotah Stone and Sharing to Gains," pp 687-701, First World Mining Environment Congress, Dec 11-14 ND India.

[2] Test Report from National Institute of Rock Mechanics, CSIR, GOI.

[3] Beneficiation Studies on Low Grade Limestone from Kotah Stone Mines: IMMT, (CSIR) GOI.

[4] Chemical Engineering's Handbook, Robert H. Perry/Cecil H. Chilton, Froth Floatation, P-65-69, P-17-29, 3.

[5] Principles of Mineral Dressing, by A. M. Gaudin, McGraw Hill Book Co., Inc New-York.

[6] "Gaudin, Floatation", 2nd Ed; McGraw-Hill New York 1957.

[7] Sutherland and Work, "Principles of Floatation" Australian Institute of Mining and Metallurgy, Melbourn.

[8] Handbook of Mineral Dressing, Willey, New York.

[9] Miller Benjamin L, and Charles H, Breerwood: Floatation Processing of Limestone, Am. Inst. Mining and Metallurgy Engr, Tech. Pub. 606.

[10] Rabone Philip: "Floatation Plant Practice" Mining Publication LTD, London, pp 79-99 and pp 100-106.

[11] Taggart, Arthur F: Floatation Reagents, Trans. Am. Inst. Mining Met. Engrs 79, 40-49.

[12] Froth Flotation "59th Anniversary Volume, American Institute of Mining, Metallurgy and Petroleum Engineering, New York, 1962.

[13] Studies on Clinkerisation and Manuacturing Portland Cement from Concentrate obtained after Beneficiation of Low Grade Limestone from Kotah Stone Waste: NCCBM: CSIR, GOI.

[14] The Cement Manufacturing Process: Darrell Leetham, USA, 08.20. 2015.

[15] Manufacture of Cement- Material \& Manufacturing Process of Portland Cement, - The Constructor", Civil Engg Home.

[16] Training Program on Manufacturing, for Overseas Cement Plant; NCCBM, CSIR, GOI.

[17] Cement Formulae Handbook: CMA, version -2 May 2010.

[18] B. P. Ravi, S. J. G. Krishna \& 4 others, Beneficiation of low grade lime stone from Madukkarai, Coimbatore, DistrictTamilnadu, India-IJMPEM, 2017, 2 (1): 1-6. 